\title{
Kadınlarda metabolik sendromun alternatif prediktörleri
}

\author{
Alternative predictors of metabolic syndrome in women
}

\author{
Yusuf Bozkuş, Umut Mousa, Nazlı Kırnap, Özlem Turhan Iyidir, Lala Ramazanova, Aslı Nar, \\ Neslihan Başçıl Tütüncü
}

\section{Özet}

Amaç: Çalışmanın amacı, metabolik sendrom (MetS) kriterleri içinde yer almayan fakat adipozite göstergesi kabul edilen parametrelerin, MetS'u olan ve olmayan kadınlar arasında farklılık gösterip göstermediğini ortaya koymak ve bu parametrelerin MetS'u u predikte eden kesim noktalarını saptamaktır.

Gereç ve yöntem: Bilinen glikoz metabolizma bozukluğu olmayan 393 kadın birey (18-70 yaş) alındı. Bu bireylerden NCEP ATPIII kriterlerine göre MetS'u olan ve olmayanlar tespit edildikten sonra, tüm katılımcıların antropometrik ve vücut yağ dağılımı ölçümleri alındı ve laboratuar parametreleri çalışıldı. ROC eğrileri çizildi ve eğri altında kalan alanlar hesaplandı. Parametrelerin MetS'u predikte eden kesim noktaları ve bu kesim noktalarının duyarlılık ve özgüllük oranları belirlendi.

Bulgular: Vücut kitle indeksi (VKi), boyun çevresi, visseral yağ düzeyi, gövde yağ yüzdesi, HOMAIR indeksi ve insülin düzeyleri için eğri altında kalan alanların 0,7'nin üstünde olduğu; kalça çevresi, bel-kalça oranı, total yağ kitlesi, total yağ yüzdesi, LDL-K, düzeyi ve TSH düzeyi için eğri altında kalan alaların ise 0,7'nin altında olduğu saptanmıştır. VKí için $27,7 \mathrm{~kg} / \mathrm{m} 2$, boyun çevresi için $33,8 \mathrm{~cm}$, bel çevresi için $91,5 \mathrm{~cm}$, visseral yağ düzeyi için 10,8 birim, gövde yağ yüzdesi için \%43,1, HOMAIR indeksi için 2,14 ve insülin düzeyi için 8,7 $\mu \mathrm{U} / \mathrm{mL}$ değerlerinin, MetS'u predikte etmedeki duyarlılıkları \%80 ve üstünde bulunmuştur.

Sonuç: VKI, boyun çevresi, visseral yağ düzeyi, gövde yağ yüzdesi, HOMAIR indeksi ve insülin düzeyleri MetS'u öngörmede değerli ölçütlerdir.

Anahtar kelimeler: Metabolik sendrom, antropometri, adipoz doku, insülin direnci.

Bozkuş Y, Mousa U, Kırnap N, Turhan İyidir Ö, Ramazanova L, Nar A, Başçıl Tütüncü N. Kadınlarda metabolik sendromun alternatif prediktörleri. Pam Tıp Derg 2020;13:341-349.

\section{Abstract}

Purpose: The aim of this study is to determine whether the parameters that are not included in the criteria of metabolic syndrome (MetS), but are considered as indicators of adiposity, differ between women with and without MetS and to determine the cut-off points of these parameters predicting MetS.

Materials and methods: A total of 393 adult women (18-70 years) with no known glucose metabolism disorder were included. After determining the participants with and without MetS, anthropometric and body fat distribution measurements of all participants were made and laboratory parameters were examined. The ROC curves were plotted and the areas under the curve were calculated. The cut-off points predicting MetS and the sensitivity and specificity ratios of these cut-off points were determined.

Results: While the area under the curve for body mass index (BMI), neck circumference, visceral fat level, trunk fat percentage, HOMAIR index and insulin levels were found to be over 0.7 , area under the curve for hip circumference, waist-hip ratio, total fat mass and total fat percentage, LDL-C levels and TSH levels were below 0.7. The sensitivities were $80 \%$ and over for the cut-off points of parameters that predict MetS for women which were found to be $27.7 \mathrm{~kg} / \mathrm{m} 2$ for BMI, $33.8 \mathrm{~cm}$ for neck circumference, $91.5 \mathrm{~cm}$ for waist circumference, 10.8 unit for visceral fat level, $43.1 \%$ for trunk fat percentage, 2.14 for HOMAIR index and $8.7 \mu \mathrm{U} / \mathrm{mL}$ for insulin levels.

Yusuf Bozkuş, Dr Öğr. Üye. Başkent Üniversitesi Tıp Fakültesi İç Hastalıkları Anabilim Dalı, Endokrinoloji Bilim Dalı, Ankara Türkiye, e-posta: yusufbozkus@yahoo.com (orcid.org/0000-0002-6976-6659) (Sorumlu Yazar)

Umut Mousa, Doç. Dr. Burhan Nalbantoğlu Devlet Hastanesi Endokrinoloji Metabolizma Hastalıkları Bölümü, Lefkoşa, Kıbrıs, e-posta: umutmousa@yahoo.co.uk (orcid.org/0000-0002-8078-9376)

Nazlı Kırnap, Uzm. Dr. Başkent Üniversitesi Tıp Fakültesi İç Hastalıkları Anabilim Dalı, Endokrinoloji Bilim Dalı, Ankara, Türkiye, e-posta: kirnapnazli@hotmail.com (orcid.org/0000-0001-7103-9963)

Özlem Turhan İyidir , Doç. Dr. Başkent Üniversitesi Tıp Fakültesi İç Hastalıkları Anabilim Dalı, Endokrinoloji Bilim Dalı, Ankara, Türkiye, e-posta: oturhaniyidir@yahoo.com (orcid.org/0000-0001-5305-6807)

Lala Ramazanova, Uzm. Dr. Başkent Üniversitesi Tıp Fakültesi İç Hastalıkları Anabilim Dalı, Endokrinoloji Bilim Dalı, Ankara, Türkiye, e-posta: ramazanova.lala@gmail.com (orcid.org/0000-0002-4141-6163)

Asıı Nar, Prof. Dr. Başkent Üniversitesi Tıp Fakültesi İç Hastalıkları Anabilim Dalı, Endokrinoloji Bilim Dalı, Ankara, Türkiye, e-posta: aslinar@ hotmail.com (orcid.org/0000-0003-0998-8388)

Neslihan Başçıl Tütüncü, Prof. Dr. Başkent Üniversitesi Tıp Fakültesi İç Hastalıkları Anabilim Dalı, Endokrinoloji Bilim Dalı, Ankara, Türkiye, e-posta: neslibascil@yahoo.com (orcid.org/0000-0002-1816-3903) 
Conclusion: BMI, neck circumference, visceral fat level, trunk fat percentage, HOMAIR index and insulin levels are valuable criteria to predict MetS.

Key words: Metabolic syndrome, anthropometry, adipose tissue, insulin resistance.

Bozkuş Y, Mousa U, Kırnap N, Turhan İyidir Ö, Ramazanova L, Nar A, Başçıl Tütüncü N. Alternative predictors of metabolic syndrome in women. Pam Med J 2020;13:341-349.

\section{Giriş}

Kardiyovasküler hastalık (KVH)'lar, tüm dünyada başta gelen ölüm sebebi olup, Dünya Sağlık Örgütü verilerine göre küresel ölümlerin \%30'unu oluşturmaktadır [1]. Küresel açıdan önemli bir sağlık sorunu oluşturan KVH'lardan korunmada, sigara, sağlıksız beslenme, obezite, fiziksel inaktivite, yüksek kan basıncı, diyabet, metabolik sendrom (MetS) ve hiperlipidemi gibi çok iyi tanımlanmış risk faktörlerini saptama ve bu faktörlerle mücadele edilmesi önemlidir [2]. MetS abdominal obezite ile ilişkili olan birtakım metabolik sorunlar kümesi olup $\mathrm{KVH}$ riskinde önemli artışa yol açmaktadır. Farkı MetS tanımları vardır. WHO (World Health Organization) [3], EGIR (the European Group for the Study of Insulin Resistance) [4], NCEP ATPIII (the National Cholesterol Education Programme Adult Treatment Panel III) [5, 6], AACE (the American Association of Clinical Endocrinologists) [7], IDF (the International Diabetes Federation) [8] bunlardan en çok bilinenleridir. En yaygın kullanılan ATPIII kriterleri, 2001 yılında NCEP ATPIII tarafından tanımlanmıştır [5] ve 2005 yılında AHA/NHLBI (American Heart Association/National Heart, Lung, and Blood Institute) tarafından revize edilmiştir [6]. Bu revizyonda, $110 \mathrm{mg} / \mathrm{dL}$ olan açlık kan glikozu sınırı ADA (American Diabetes Association)'nın bozulmuş açlık glikozu (BAG) için önerdiği $100 \mathrm{mg} / \mathrm{dL}$ sınırına çekilmiştir. Ayrıca hiperlipidemi ve hipertansiyon için ilaç kullanımlarının da kriterlere dahil edilmesi sağlanmıştır [6]. MetS prevelansı giderek artmaktadır. NCEP ATPIII kriterlerine göre MetS prevelansı 1996'da \%21,8 iken, 2005'te bu oran \%35'e çıkmıştır [9, 10]. Avrupa'da MetS hastalarında tüm nedenlere bağlı ve kardiyovasküler (KV) mortalitede belirgin bir artış izlenmiştir. Benzer sonuçlar İngiliz, İskandinav ve Amerikan toplumlarında da gözlenmiştir [11].

Metabolik sendrom sık görülen bir hastalık olması, artan prevalansı, KVH riskinde belirgin artışa yol açması ve mortaliteyi arttırması nedeniyle önemli bir toplumsal sağlık sorunu haline gelmiştir. Tanı konulduğunda, kriterlerde yer alan çok sayıda sağlık sorunu gelişmiş olduğu için, çok sayıda morbiditeyi tedavi etmek gerekmekte ve bu durum hastalıkla mücadeleyi zorlaştırmaktadır. $\mathrm{Bu}$ nedenle MetS tanısını öngören klinik bulguları belirleyip, daha hastalık kriterleri ortaya çıkmadan önlem almak, diğer koruyucu hekimlik uygulamalarında olduğu gibi MetS gelişme sıklığını ve buna bağlı morbidite ve mortaliteyi azaltabilecektir. Bu çalışmada, MetS kriterleri içinde yer almayan ve adipozite göstergesi kabul edilen diğer parametrelerin, MetS olan ve olmayan kadınlar arasında farklılık gösterip göstermediğini ortaya koymak amaçlanmıştır.

\section{Gereç ve yöntem}

Bu çalışma Başkent Üniversitesi Tıp ve Sağlık Bilimleri Araştırma ve Etik Kurulu tarafından onaylanmış (Proje no: KA19/405) ve Başkent Üniversitesi Araştırma Fonunca desteklenmiştir. Çalışma verileri, daha önce kliniğimizde yapılan KA12/109 ve KA12/192 proje kodlu çalışmalarımızda yer alan katılımcıların verilerinin geriye dönük olarak derlenmesiyle elde edilmiştir. Endokrinoloji ve Metabolizma Hastalıkları Polikliniği'ne, Haziran 2011 ile Haziran 2013 tarihleri arasında kilo vermek için başvuran ve bilinen glikoz metabolizma bozukluğu olmayan 393 kadın (18-70 yaş) çalışmaya dahil edildi. Bu bireylerden NCEP ATPIII kriterlerine göre MetS olan ve olmayanlar tespit edildikten sonra, tüm katılımcıların antropometrik ölçümleri ve vücut yağ dağılımı ve laboratuar parametreleri kaydedildi.

Bilinen glikoz tolerans bozukluğu olup oral antidiyabetik, insülin, anti-obezite tedavi alanlar; anti-depresan ya da anti-psikotik ilaç kullananlar; steroid veya hormon replasman tedavisi alanlar; reçetesiz satılan kilo verdirici ilaçları kullananlar veya herhangi bir hastalık için bitkisel karışım ilaç kullanan hastalar gibi, kilo ve glikoz metabolizmasına etkili ilaçları almakta olanlar çalışmaya alınmadı. Ayrıca yaşı 
$>70$ ve <18 olanlar, konjestif kalp yetmezliği, kronik böbrek hastalığı, inme, kanser öyküsü olanlar, kalp pili olanlar, kalp kapak replasmanı yapılmış hastalar, gastrointestinal sistem cerrahisi geçirenler, inflamatuvar barsak hastalığı ve diğer malabsorbsiyon sendromları olanlar, kronik karaciğer hastalığı olanlar, ötiroid olmayanlar ve gebeler çalışmaya alınmadı.

Bireylerin vücut ağırlığı (VA), kilogram (kg) cinsinden; boy, santimetre $(\mathrm{cm})$ cinsinden ölçüldü. Vücut kütle indeksi (VKI), hastanın kilogram cinsinden vücut ağırlığının, metre cinsinden boyunun karesine bölünmesiyle elde edildi $\left(\mathrm{kg} / \mathrm{m}^{2}\right)$. Bel çevresi (BÇ), umbilikus bölgesinden hasta ayakta iken, yere paralel olarak bir mezura yardımı ile ölçüldü. Boyun çevresi, hasta ayakta iken laringeal çıkıntının hemen üzerinden yere paralel olarak bir mezura yardımı ile ölçüldü. Bel/kalça oranı (BKO), manüel ölçülen bel çevresinin, kalça çevresine oranı ile hesaplandı. Visseral adipoz doku (VAD) düzeyi ve gövde adipoz doku (GAD) yüzdesi bir abdominal bioimpedans analiz (BİA) cihazı olan "AB-140 ViScan cihazı (Tanita, Tokyo, Japonya)" ile ölçüldü. Tüm vücut adipoz doku (TVAD) kütlesi ve yüzdesi, konvansiyonel BİA cihazı olan "TBF-300 body composition analyzer" (Tanita corp, Tokyo, Japonya) ile ölçüldü. Ölçüm, her hasta için yaklaşık 60 saniye sürdü. Gönüllüler, ölçümden 24 saat öncesinden alkol almamaları, ölçümden 4 saat öncesinden kafein içeren içecek tüketmemeleri konusunda uyarıldılar. Sonuçları etkileme potansiyeli olan ağır kıyafetler, küpe, yüzük ve benzeri takıların ölçüm öncesi çıkartılması istendi. Ölçümler, en az 8-10 saatlik açlıktan sonra alındı.

Bütün gönüllülerden venöz kan örneği ile açlık plazma glikozu (APG, mg/dL), açlık insülin $(\mu \mathrm{U} / \mathrm{mL})$, trigliserit ( $T G, \mathrm{mg} / \mathrm{dL})$, yüksek dansiteli lipoprotein kolesterolü (HDL-K, mg/ $\mathrm{dL}$ ), düşük dansiteli lipoprotein kolesterolü (LDL-K, $\mathrm{mg} / \mathrm{dL}$ ), tiroid stimüle edici hormon (TSH, IU/mL) düzeyleri çalışıldı. TSH ve insülin ölçümleri "imunokemiluminasan assay" yöntemi ile çalışıldı (Architect c8200, Abbott). APG "Hexokinase/G-6-PDH" yöntemi (Architect c8200, Abbott), LDL-K "Measured, Liquid Selective Detergent" direk yöntemi (Architect c8200, Abbott), HDL-K "Accelerator Selective Detergent" direk yöntemi (Architect c8200, Abbott) ve TG düzeyi "Glycerol Phosphate Oxidase" yöntemi ile (Architect c8200, Abbott) çalışıldı. Ayrıca bir sfingomanometre ile hasta en az 15 dakika istirahat ettikten sonra, oturur pozisyonda, sağ koldan kan basıncı ölçümü yapıldı.

Prediyabet ve diyabet tanıları, ADA kriterlerine göre konuldu [12]. Buna göre: APG, $100-125 \mathrm{mg} / \mathrm{dL}$ ve/veya tokluk plazma glikozu (TPG), 140-199 mg/dL olan bireylerin, prediyabet; 2 farklı ölçümde APG $\geq 126 \mathrm{mg} /$ $\mathrm{dL}$ ve/veya TPG $\geq 200 \mathrm{mg} / \mathrm{dL}$ olan bireylerin, diyabet tanısı olduğu kabul edildi. Tekrarlayan ölçümlerde sistolik kan basıncı $\geq 140 \mathrm{mmHg}$ ve/ veya diastolik kan basıncı $\geq 90 \mathrm{mmHg}$ olanlar veya antihipertansif ilaç kullanan bireylerde hipertansiyon olduğu kabul edildi [13]. LDL-K düzeyi $\geq 130 \mathrm{mg} / \mathrm{dL}$ olanlar veya statin grubu ilaç alan bireylerde hiperlipidemi olduğu kabul edildi [5]. HOMAIR (Homeostasis model assessment of insulin resistance) skoru, "açlık kan glikozu x açlık insülin/405" formülü ile hesaplandı (Açlık insülin için " $\mu \mathrm{IU} / \mathrm{ml}$ ", açlık glikozu için "mg/dL" birimleri kullanıldı) [14].

Gönüllülerdeki MetS varlığı için NCEP ATP III kriterleri (1. Erkeklerde $B C ̧ \geq 102 \mathrm{~cm}$, Kadınlarda $\mathrm{BÇ} \geq 88 \mathrm{~cm}$ olması; 2. APG $\geq 100 \mathrm{mg} / \mathrm{dL}$ veya ilaç tedavisi alıyor olmak; 3 . TG $\geq 150 \mathrm{mg} / \mathrm{dL}$ veya ilaç tedavisi alıyor olmak; 4. HDL-K <40 $\mathrm{mg} / \mathrm{dL}$ (Erkek), $<50 \mathrm{mg} / \mathrm{dL}$ (Kadın) veya ilaç tedavisi alıyor olmak; 5 . KB $\geq 130 / 85 \mathrm{mmHg}$ veya antihipertansif tedavi alıyor olması) [5] kullanıldı. Beş kriterden en az üç tanesi pozitif olan bireylere MetS tanısı konuldu.

Verilerin normal dağılıma uyup uymadığı Kolmogorov-Smirov testi ile değerlendirildi. Normal dağılıma uyan verilerin karşılaştırması T-test, normal dağılıma uymayan veriler Mann-Whitney $U$ ile karşılaştırıldı. ROC eğrisi ile eğri altındaki alanlar (EAA) saptandı ve parametrelerin MetS'u predikte eden kesim noktaları ve bu kesim noktalarının duyarlılık ve özgüllük oranları belirlendi. Araştırmanın istatistikleri SPSS for Windows v16.0 (Statistical Package for Social Sciences; Chicago, IL) paket programı kullanılarak yapılmıştır. $p$ değerinin $<0,05$ olması istatistiksel açıdan anlamlı kabul edildi. 


\section{Bulgular}

Çalışmaya alınan 393 kadın bireyin 94 (\%24)) ünde MetS saptanmıştır. MetS olanların yaş, VA, VKI, boyun çevresi, bel çevresi, kalça çevresi, BKO, visseral yağ miktarı, gövde yağ yüzdesi, total yağ kütlesi ve yüzdesi, MetS olmayanlara göre daha yüksek bulunmuştur $(p>0,001)$ (Tablo 1). Ayrıca MetS olanların HOMAIR indeksleri, açlık insülin düzeyleri ve LDL düzeyleri MetS olmayanlara göre daha yüksek bulunmuştur $(p>0,001)$ (Tablo 1$)$. TSH düzeyi de MetS olanlarda daha yüksek bulunmuştur, ancak istatistiksel anlamlı değildir $(p=0,135)$ (Tablo 1$)$. MetS'u predikte eden parametrelerden, VKI, boyun çevresi, visseral yağ miktarı, gövde yağ yüzdesi,
HOMAIR indeksi ve insülin düzeylerinin, EAA'larının 0,7'nin üstünde olduğu ve NCEP ATPIII kriterlerinde yer alan parametreler olan BÇ, APG, TG ve HDL-K düzeyinin EAA'larına benzer olduğu saptanmıştır (Tablo 2). Kalça Çevresi, BKO, konvansiyonel BİA ile ölçülen total yağ kütlesi ve yağ yüzdesinin, LDL-K ve TSH düzeyinin, EAA'ları ise $<0,7$ saptanmıştır. Eğri altındaki alanlar, kesim noktaları, duyarlılık ve özgüllük oranları Tablo 2'de verilmiştir. VKi için $27,7 \mathrm{~kg} / \mathrm{m}^{2}$, boyun çevresi için $33,8 \mathrm{~cm}$, bel çevresi için $91,5 \mathrm{~cm}$, visseral yağ miktarı için 10,8 birim, gövde yağ yüzdesi için $\% 43,1$, HOMAIR indeksi için 2,14 ve insülin düzeyi için $8,7 \mu \mathrm{U} / \mathrm{mL}$ değerlerinin MetS predikte etmedeki duyarlııkları $\% 80$ ve üstünde bulunmuştur (Tablo 2).

Tablo 1. Metabolik parametrelerin metabolik sendrom olanlarda ve olmayanlarda karşılaştırılması.

\begin{tabular}{|c|c|c|c|}
\hline & \multicolumn{2}{|c|}{ Metabolik sendrom } & \multirow{2}{*}{$p$} \\
\hline & Yok $(n=299)$ & $\operatorname{Var}(n=94)$ & \\
\hline Yaş (yıl) & 37,3 & 46,6 & $<0,001$ \\
\hline Vücut ağırlığı (kg) & 73,1 & 82,8 & $<0,001$ \\
\hline Beden kitle indeksi $\left(\mathrm{kg} / \mathrm{m}^{2}\right)$ & 27,8 & 32,0 & $<0,001$ \\
\hline Boyun Çevresi (cm) & 34,2 & 36,4 & $<0,001$ \\
\hline Bel Çevresi $(\mathrm{cm})$ & 92,4 & 102,2 & $<0,001$ \\
\hline Kalça Çevresi (cm) & 107,3 & 112,3 & $<0,001$ \\
\hline Bel-kalça oranı & 0,86 & 0,91 & $<0,001$ \\
\hline Abdominal BİA Gövde Yağı (\%) & 42,1 & 47,0 & $<0,001$ \\
\hline Abdominal BİA Visseral Yağ & 10,8 & 14,0 & $<0,001$ \\
\hline Konvansiyonel BİA Total Yağ Kitlesi (kg) & 26,8 & 34,0 & $<0,001$ \\
\hline Konvansiyonel BíA Yağ Yüzdesi (\%) & 35,2 & 40,0 & $<0,001$ \\
\hline HOMAIR İndeksi & 2,17 & 3,19 & $<0,001$ \\
\hline İnsülin $(\mu \mathrm{U} / \mathrm{mL})$ & 9,5 & 12,9 & $<0,001$ \\
\hline Açlık kan glikozu (mg/dL) & 91,1 & 100,3 & $<0,001$ \\
\hline LDL-Kolesterol (mg/dL) & 119,7 & 135,1 & $<0,001$ \\
\hline HDL-Kolesterol (mg/dL) & 53,7 & 41,3 & $<0,001$ \\
\hline Trigliserit (mg/dL) & 96 & 181 & $<0,001$ \\
\hline $\mathrm{TSH}(\mu \mathrm{IU} / \mathrm{mL})$ & 1,96 & 2,23 & 0,135 \\
\hline
\end{tabular}

LDL: Düşük dansiteli lipoprotein, HDL: Yüksek dansiteli lipoprotein, TSH: Tiroid stimüle edici hormon 
Tablo 2. Metabolik sendromu öngören değişkenlerin ROC analiz sonuçları.

\begin{tabular}{|c|c|c|c|c|c|c|}
\hline & EAA & $\mathrm{SH}$ & $p$ & KN & $\begin{array}{l}\text { Duy. } \\
\text { (\%) }\end{array}$ & $\begin{array}{l}\text { Özg. } \\
(\%)\end{array}$ \\
\hline \multicolumn{7}{|c|}{ Metabolik Sendrom ATPIII Kriterleri içinde yer alan parametreler } \\
\hline Bel Çevresi (cm) & 0,709 & 0,032 & $<0,001$ & 91,5 & 83 & 46 \\
\hline Açlık kan glikozu (mg/dL) & 0,753 & 0,036 & $<0,001$ & 91 & 80 & 50 \\
\hline HDL-Kolesterol (mg/dL) & 0,798 & 0,024 & $<0,001$ & 43 & 80 & 60 \\
\hline Trigliserit (mg/dL) & 0,867 & 0,027 & $<0,001$ & 127 & 83 & 80 \\
\hline \multicolumn{7}{|c|}{ Metabolik Sendrom ATPIII Kriterleri içinde olmayan parametreler } \\
\hline Beden kitle indeksi $\left(\mathrm{kg} / \mathrm{m}^{2}\right)$ & 0,718 & 0,032 & $<0,001$ & 27,7 & 82 & 52 \\
\hline Boyun Çevresi (cm) & 0,752 & 0,031 & $<0,001$ & 33,8 & 92 & 42 \\
\hline Kalça Çevresi (cm) & 0,644 & 0,036 & $<0,001$ & 103,5 & 83 & 48 \\
\hline Bel-kalça oranı & 0,673 & 0,033 & $<0,001$ & 0,87 & 80 & 43 \\
\hline Abdominal BİA Gövde Yağı (\%) & 0,711 & 0,033 & $<0,001$ & 43,1 & 82 & 51 \\
\hline Abdominal BİA Visseral Yağ & 0,728 & 0,031 & $<0,001$ & 10,8 & 82 & 52 \\
\hline Konvansiyonel BìA Total Yağ Kitlesi (kg) & 0,689 & 0,034 & $<0,001$ & 25,2 & 80 & 46 \\
\hline Konvansiyonel BíA Yağ Yüzdesi (\%) & 0,687 & 0,034 & $<0,001$ & 34,8 & 80 & 44 \\
\hline HOMAIR İndeksi & 0,758 & 0,032 & $<0,001$ & 2,14 & 80 & 64 \\
\hline İnsülin $(\mu \mathrm{U} / \mathrm{mL})$ & 0,723 & 0,033 & $<0,001$ & 8,7 & 80 & 55 \\
\hline LDL-Kolesterol (mg/dL) & 0,625 & 0,037 & 0,001 & 103 & 80 & 28 \\
\hline $\mathrm{TSH}(\mu \mathrm{IU} / \mathrm{mL})$ & 0,535 & 0,040 & 0,359 & 1,15 & 80 & 22 \\
\hline
\end{tabular}

EAA: Eğri altında kalan alan, SH: Standart hata, KN: Kesim noktası, Duy.: Duyarlılık, Özg.: Özgüllük, HDL: Yüksek dansiteli lipoprotein, LDL: Düşük dansiteli lipoprotein, TSH: Tiroid stimüle edici hormon

\section{Tartışma}

Vücut kütle indeksi, jeneralize obeziteyi tanımlamak için en sık kullanılan yöntemlerden birisidir. Çalışmamızda VKI'nin EAA değeri MetS kriteri olmamasına rağmen bir MetS kriteri olan bel çevresiyle benzer bulunmuştur $(0,718$ vs 0,709$)$. Türkiye'de 2010 yılında, 26.000'den fazla kişinin incelendiği TURDEP-2 verilerine göre, 12 yıl içinde (1998-2010) yaşa göre standardize edilmiş ortalama VKi değerleri, 26,6'dan 28,6 kg/m²'ye çıkmıştır. Diyabet prevalansındaki değişim ile ortalama VKl'deki değişim arasında güçlü korelasyonlar saptanmıştır $(r=0,709)$. Diyabet prevalansındaki değişim ile ortalama VKi'deki değişim arasındaki korelasyon, diyabet prevalansındaki değişim ile ortalama bel çevresindeki değişim arasındaki korelasyona göre daha güçlü görünmektedir ( $r=0,709$ vs $r=0,651) \quad$ [15]. Ayrıca yapılan çalışmalarda VKi ile gelişmiş yöntemlerle ölçülen visseral yağ arasında güçlü korelasyonlar saptanmıştır $(r=0,813, r=0,849)$ [16-18]. Çalışmamız, literatüre benzer şekilde VKI'nin önemini vurgulamakla birlikte, kadınlarda VKI için $27,7 \mathrm{~kg} / \mathrm{m}^{2}$ kesim noktasının \%80 duyarlııkla MetS'u öngörebildiğini göstermiştir. Ancak çalışmamızda, vücut geliştirme sporu yapan kişiler gibi yağsız vücut kütlesi fazla olan bireyler yoktur ve VKi, bu kişilerde dikkatli yorumlanmalıdır. 
Literatürde boyun çevresi ile metabolik sendrom ve insülin direnci arasında ilişki olduğunu gösteren çok sayıda çalışma mevcuttur. "Brezilya Metabolik Sendrom" çalışmasında her iki cinsiyette de boyun çevresi ile HOMAIR, açlık insülin, trigliserit düzeyi ve USG ile ölçülen visseral yağ dokusu arasında pozitif korelasyon ve HDL arasında negatif korelasyonlar saptanmıştır [19]. Türkiye'de yapılmış bir çalışmada ise [20] ortalama yaşı 55 olan 1912 normal glikoz toleransı olan kişide ortalama boyun çevresi, erkeklerde $38,8 \mathrm{~cm}$, kadınlarda $34,8 \mathrm{~cm}$ bulunmuştur. MetS'u en iyi predikte eden boyun çevresi eşik değerleri için kadında $\geq 35 \mathrm{~cm}$ (\%65 sensitivite, $\% 67$ spesifite) saptanmıştır. Ayrıca boyun çevresi çok sayıda risk faktörüyle, özellikle beden kütle indeksi, bel çevresi, HOMAIR skoru ve kan basıncıyla ilişkili bulunmuştur. Bizim çalışmamızda da boyun çevresi eşik değerinin $\geq 34,8 \mathrm{~cm}$ olması $\% 74$ sensitivite, \%61 spesifite ile MetS'u öngörebilmiştir ve bu rakamlar yukarıdaki çalışma ile benzerdir. Öte yandan çalışmamızda kadınlarda boyun çevresi için $33,8 \mathrm{~cm}$ kesim noktasının MetS öngörmede duyarlılığı \%92 saptanmış olup bu değerin özgüllüğü \%42 saptanmıştır. Ayrıca çalışmamızda boyun çevresinin EAA değeri MetS kriteri olmamasına rağmen bir MetS kriteri olan bel çevresinden daha fazla bulunmuştur $(0,752$ vs 0,709$)$. Bu veriler ve mevcut literatür bilgisine göre, boyun çevresi ölçümü, MetS'u öngörmede değerli bir gösterge olabilir. Ancak hangi boyun çevresi kesim noktasının metabolik sorunları en iyi gösterebildiği ile ilgili yeterli çalışma olmaması, klinik pratikte yaygın kullanılması önündeki bir engel gibi durmaktadır. Ancak çalışmamız ve daha önceki veriler ışığında, yeni daha büyük çalışmalar yapılana kadar, Türkiye için kadınlarda boyun çevresi için 33,8 cm değerinin kullanılması önerilebilir.

Literatürde BKO ile MetS arasında yakın korelasyon olduğunu ve BKO arttıkça, MetS riskinin de arttığını gösteren çok sayıda çalışma vardır ve kadınlarda $\geq 0,85$ olmasının, olumsuz kardiyovasküler risk profili ile ilişkili olduğu saptanmış ve WHO ve EGIR tarafından kabul görmüştür [8, 21]. Ancak bazı çalışmalarda ise VAD'yu tahmin etmede yeterli doğruluk oranlarına sahip olmadığı gösterilmiştir [16, 17, 22]. Çalışmamızda da BKO için eğri altında kalan alan $<0,7$ saptanmıştır ve diğer parametrelere göre MetS'u öngörmede değeri düşüktür. Çalışmamızda, her ne kadar bel çevresi için eğri altında kalan alan $>0,7$ saptansa da antropometrik ölçümler içinde, eğri altında kalan alanı en düşük olan veri, kalça çevresi olmuştur $(0,644)$. Alt vücut bölgesinde yer alan yağ dokusunun büyük kısmı gluteal ve femoral bölge yerleşimlidir ve tamamı subkütan yağ dokusundan oluşmaktadır [23]. Bu nedenle kalça çevresi ölçümünün, yalnızca subkütan yağ dokusunu yansıttığı düşünülmektedir [22]. Literatürde de gluteal-femoral tip yağlanma ile metabolik bozukluklar arasındaki ilişkiyi gösteren kanıtlar, santral yağlanma ile metabolik bozukluklar arasındaki ilişkiyi gösteren kanıtlara göre çok daha azdır [24]. Bu nedenle kalça çevresi ölçümünün, klinik pratikte ve klinik araştırmalarda, özellikle BKO'ını hesaplarken klinik önemi vardır. Hem kalça çevresi için elde edilen EAA değerinin düşük olması, hem de bel çevresi ölçümündeki olası ölçüm hataları, BKO ile ilgili sonuçları olumsuz yönde etkilemiş olabilir.

Çalışmamızda konvansiyonel BìA cihazı ile ölçülen TVAD kütlesi ve yüzdesi için de eğri altında kalan alan <0,7 saptandı. Yapılan birçok çalışmada vücuttaki esas patojenik yağ dokusunun, visseral yağ dokusu başta olmak üzere ektopik yağ depoları olduğu artık iyi bilinmektedir [24, 25]. Literatürde de bildirildiği gibi konvansiyonel BİA yöntemleri, tüm vücut yağ içeriğini tahmin ederken, bölgesel yağ dokuları hakkında bilgi vermemektedir [26]. Çalışmamızda da konvansiyonel BìA cihazının, MetS'u öngörmedeki değerinin diğer ölçümlere göre düşük olduğu görülmektedir. Bu nedenle klinik pratikte, konvansiyonel BİA ile elde edilen verilere intiyatla yaklaşmakta fayda vardır. Ancak çalışmamızda, kadınlarda tüm vücut yağ kütlesinin \%34,8ıden fazla olmasının \%80 duyarlılık ile MetS'u öngördüğü saptanmıştır (AUC:0,687) ve bu oran literatürde bildirilen oranlarla benzerlik göstermektedir [27].

Abdominal BIA cihazı ile ölçülen gövde yağı ve visseral yağ düzeylerinin EAA değeri $>0,7$ olup, MetS'u öngörmede değeri, konvansiyonel BIA cihazının aksine fazladır. Cihazın, ölçümler arası değişkenliği çok düşük olup, ölçen kişiden etkilenmiyor olması da önemli bir avantajıdır. Kliniğimizde yaptığımız, diyet sonrası antropometrik ölçümlerdeki değişim ile HOMA skorundaki değişim arasındaki ilişkiyi incelediğimiz çalışmada, HOMA skorundaki 
değişim ile en iyi bağımsız ilişki, abdominal BİA cihazı ile ölçülen visseral yağ arasındaki saptanmıştır [28]. Bu nedenle tedavi sonrası değişiklikleri göstermesi açısından faydalı olabileceğini düşünüyoruz. Abdominal BİA da konvansiyonel BİA yöntemlerinde olduğu gibi noninvaziv olup, DEXA (dual enerji x-ray absorpsiyometri), BT (bilgisayarlı tomografi) ve MRG (manyetik rezonans görüntüleme) gibi bölgesel yağ ölçüm yöntemlerine göre ucuz, pratik ve zaman almayan bir yöntemdir ve radyasyon içermemektedir. Bu avantajların yanı sıra tekrarlanabilir olması, diğer olumlu bir yönüdür. Ancak literatürde bu cihazlardan elde edilen veriler çok az olduğu için MetS'u öngören kesim değeri ile ilgili yorum yapmak çok zordur. Kliniğimizde daha önce yaptığımız başka bir çalışmada, AB-140 cihazı ile kadınlarda visseral yağ dokusunun 9,8 ve üzerinde bulunmasının, MetS varlığını \%90 duyarlılık ile predikte ettiği gösterilmiştir [29]. Vaka sayısının daha çok olduğu mevcut çalışmada ise 9,8'in duyarlılığı \%89 saptanmıştır, fakat özgüllüğü oldukça düşüktür. Çalışmamızda gövde yağı için $\% 43,1$, visseral yağ için 10,8 değerlerinin MetS'u \%82 duyarlılıkla öngördüğü saptanmıştır.

Çalışmamızda açlık insülin düzeyi için 8,7 $\mu \mathrm{U} / \mathrm{mL}$ değerinin (AUC:0,723), HOMAIR skoru için 2,14 değerinin (AUC:0,758) MetS'u öngörmedeki duyarlılığı \%80 saptanmıştır. Türkiye'de yapılan, 28 yaş ve üzeri 1683 erkek ve 1718 kadının incelendiği başka bir çalışmada da, HOMAIR>2,1 olmasının MetS'u olan bireylerde koroner kalp hastalığı riskini belirgin artırdığı gösterilmiştir [30]. Ancak ırksal farklılıklar da olabileceği için HOMAIR eşik değerinin tüm popülasyonlara ne kadar uygulanabileceği tartışmalıdır. Bugüne kadar değişik popülasyonlarda yapılmış pek çok çalışmada farklı yöntemlerle, faklı HOMAIR eşik değerleri bildirilmiştir. Kore'de yapılan 976 non-diyabetik bireyin incelendiği çalışmada ATPIII kriterlerine göre MetS'u predikte eden eşik değer: $\geq 2,34$ (ROC analizi kullanılmıştır) bulunmuştur [31]. İran'da yapılan 3071 ve 1276 non-diyabetik bireyin incelendiği iki çalışmada ATPIII kriterlerine göre MetS'u predikte eden eşik değerler sırası ile $\geq 1,77$ ve $\geq 1,95$ (ROC analizi kullanılmıştır) bulunmuştur $[32,33]$. Türkiyede yapılan 1348 normal glikoz metabolizmalı bireyde HOMAIR değerinin >2,245 olmasının $\mathrm{KVH}$ riskini artırdığı saptanmıştır [34]. UKPDS çalışmasında olduğu gibi [35] HOMA indekslerinin uzun dönemde beta hücre fonksiyonu ve insülin direncini değerlendirmede, diyabetin doğal seyrini saptamada ve tedavinin etkisini ortaya koymada faydalı olabileceği bildirilmektedir [14]. Ancak HOMA indeksi için \%7,8-\%11,7 arasında değişen varyasyon katsayısı halen daha önemli bir sorun gibi görünmektedir [14]. Çalışmamızda, MetS kriterlerinden olmayan açlık insülin düzeyi ve HOMAIR skorunun EAA değerleri $>0,7$ saptanmıştır. NCEP ATPIII kriterleri içinde insülin direnci yer almasa da, Dünya Sağlık Örgütü MetS kriterleri içinde ana kriteri oluşturmaktadır [3]. Henüz açlık kan glikoz yüksekliği ortaya çıkmadan çok daha önce insülin direnci saptanabileceği için, kötü metabolik riski daha erken ortaya koymak açısından insülin direncinin ölçülmesini önermekteyiz. Ülkemizde yapılan diğer çalışmalar [30, 34] ve çalışmamızın verilerine göre HOMAIR>2,1 olmasının MetS için iyi bir alternatif prediktör olabileceği düşünülebilir. Çalışmamızın laboratuvar parametrelerinden HDL, trigliserit ve açlık plazma glikozu, MetS kriterleri içinde yer alan parametreler olup, kriterleden olmayan LDL ve TSH düzeyinin EAA değerleri oldukça düşük saptanmıştır ve MetSıu öngörmede kullanılmasını önermiyoruz.

Çalışmamı, bazı kısıtlılıklar barındırmaktadır. Öncelikle vaka sayısı nispeten azdır. Kesitsel bir çalışma olup, bu ölçümlerin uzun vadede morbidite ve mortalite gibi kavramlar üzerine etkisi bilinmemektedir. Çalışmamızın konusu hakkında, çok fazla ulusal veri olmadığı için çalışma sonuçlarını karşılaştırabileceğimiz yeterli literatür bilgisi bulunmamaktadır. Çalışmamız, bu kısıtlılıkları yanı sıra önemli avantajlar sunmaktadır. Klinikte kullanılabilecek, basit, pratik ve metabolik riskleri öngörebilecek antropometrik ölçümler hakkında değerli sonuçlar elde edilmiştir. Ayrıca ırksal farklılıklar gösterebilecek antropometrik ölçümler hakkında, yetersiz olan Türkiye verisi açısından ulusal literatüre katkı sunmaktadır.

Sonuç olarak, ATPIII MetS kriterlerinden olan bel çevresi, açlık glikozu, HDL ve trigliserit düzeyine ek olarak, kriterler içinde yer almayan vücut kütle indeksi, boyun çevresi, abdominal BİA ile ölçülen gövde yağı ve visseral yağ değerlerinin ve HOMAIR skoru ve açlık insülin düzeylerinin MetS'u için alternatif prediktörler olabileceğini ve klinik pratikte hasta değerlendirmesinde ve 
takibinde faydalı olabileceklerini düşünüyoruz. Ayrıca boyun çevresi ve HOMAIR skorunun EAA değerlerinin yüksek olması bu parametrelerin değerini artırmaktır. Öte yandan kalça çevresi, BKO, konvansiyonel BIA cihazı ile ölçülen total yağ kütlesi veya yüzdesinin, LDL ve TSH düzeylerinin MetS'u öngörmede değeri düşük görünmektedir. Tüm bu parametrelerdeki değişimi inceleyen, uzun takip süresi olan ve bu parametrelerle morbidite ve mortalite arası ilişkiyi ortaya koyabilecek prospektif çalışmalar bu alanda literatüre önemli katkı sağlayacaktır.

Çıkar ilişkisi: Yazarlar çıkar ilişkisi olmadığını beyan eder.

\section{Kaynaklar}

1. Global status report on noncommunicable diseases 2010. Available at: https://apps.who.int/iris/ bitstream/handle/10665/44579/9789240686458_ eng.pdf?sequence $=1$. Accessed October 10, 2019

2. 2008-2013 Action plan for the global strategy for the prevention and control of non communicable diseases. Available at: https://apps.who.int/iris/ bitstream/handle/10665/44009/9789241597418_ eng.pdf?sequence $=1$.

Accessed October 10, 2019

3. Definition, diagnosis and classification of diabetes mellitus and its complications. Report of a WHO consultation. Part 1: diagnosis and classification of diabetes mellitus. Available at: https://apps.who.int/ iris/bitstream/handle/10665/66040/WHO_NCD_NC S_99.2.pdf?sequence=1\&isAllowed $=y$. Accessed October 10, 2019

4. Balkau B, Charles MA. Comment on the provisional report from the WHO consultation. European Group for the Study of Insulin Resistance (EGIR). Diabet Med 1999;16:442-443. https://doi.org/10.1046/j.14645491.1999.00059.x

5. Expert panel on detection, evaluation, and treatment of high blood cholesterol in adults. Executive summary of the third report of the national cholesterol education program (NCEP) expert panel on detection, evaluation, and treatment of high blood cholesterol in adults (Adult Treatment Panel III). JAMA 2001;285:2486-2497. https://doi.org/10.1001/jama.285.19.2486

6. Grundy SM, Cleeman JI, Daniels SR, et al. Diagnosis and management of the metabolic syndrome: an American Heart Association/National Heart, Lung, and Blood Institute Scientific Statement. Circulation 2005;112:2735-2752. https://doi.org/10.1161/ CIRCULATIONAHA.105.169404
7. Bloomgarden ZT. American Association of Clinical Endocrinologists (AACE) consensus conference on the insulin resistance syndrome. Washington, Diabetes Care 2003;26:1297-1303. https://doi.org/10.2337/ diacare.26.4.1297

8. Alberti KG, Zimmet P, Shaw J. Metabolic syndrome-a new world-wide definition. A Consensus Statement from the International Diabetes Federation. Diabet Med 2006;23:469-480. https://doi.org/10.1111/j.14645491.2006.01858.x

9. Ford ES, Giles WH, Dietz WH. Prevalence of the metabolic syndrome among US adults: findings from the third National Health and Nutrition Examination Survey. JAMA 2002;287:356-359. https://doi. org/10.1001/jama.287.3.356

10. Ford ES. Prevalence of the metabolic syndrome defined by the International Diabetes Federation among adults in the U.S. Diabetes Care 2005;28:2745-2749. https:// doi.org/10.2337/diacare.28.11.2745

11. Ritchie SA, Connell JM. The link between abdominal obesity, metabolic syndrome and cardiovascular disease. Nutr Metab Cardiovasc Dis 2007;17:319-326. https://doi.org/10.1016/j.numecd.2006.07.005

12. Standards of medical care in diabetes-2013- position statement. American Diabetes Association. Diabetes Care 2013;36:11-66. https://doi.org/10.2337/ dc13-S011

13. Chobanian AV, Bakris GL, Black HR, etal. The seventh report of the joint national committee on prevention, detection, evaluation, and treatment of high blood pressure: the JNC 7 report. JAMA 2003;289:25602572. https://doi.org/10.1001/jama.289.19.2560

14. Wallace TM, Levy JC, Matthews DR. Use and abuse of homa modeling. Diabetes Care 2004;27:1487-1495. https://doi.org/10.2337/diacare.27.6.1487

15. Satman I, Dinccag N, Turker F, et al. Twelve-year trends in the prevalence and risk factors of diabetes and prediabetes in Turkish adults (TURDEP-2). Eur J Epidemiol 2013;28:169-180. https://doi.org/10.1007/ s10654-013-9771-5

16. Kvist H, Chowdhury B, Grangard U, Tylen U, Sjostrom L. Total and visceral adipose-tissue volumes derived from measurements with computed tomography in adult men and women: predictive equations. Am J Clin Nutr 1988;48:1351-1361. https://doi.org/10.1093/ ajcn/48.6.1351

17. Seidell JC, Oosterlee A, Deurenberg P, Hautvast JG, Ruijs JH. Abdominal fat depots measured with computed tomography: effects of degree of obesity, sex, and age. Eur J Clin Nutr 1988;42:805-815.

18. Unno M, Furusyo $\mathrm{N}$, Mukae $\mathrm{H}$, Koga $\mathrm{T}$, Eiraku $\mathrm{K}$, Hayashi $\mathrm{J}$. The utility of visceral fat level by bioelectrical Impedance analysis in the screening of metabolic syndrome-the results of the Kyushu and Okinawa population study (KOPS). J Atheroscler Thromb 2012;19:462-470. https://doi.org/10.5551/jat. 11528 
19. Stabe C, Vasques AC, Lima MM, et al. Neck circumference as a simple tool for identifying the metabolic syndrome and insulin resistance: results from the Brazilian Metabolic Syndrome Study. Clin Endocrinol (Oxf) 2013;78:874-881. https://doi. org/10.1111/j.1365-2265.2012.04487.x

20. Onat A, Hergenç $G$, Yüksel $H$, et al. Neck circumference as a measure of central obesity: associations with metabolic syndrome and obstructive sleep apnea syndrome beyond waist circumference. Clin Nutr 2009;28:46-51. https://doi.org/10.1016/j. clnu.2008.10.006

21. Waist circumference and waist-hip ratio: report of a WHO expert consultation. Geneva, 2008. Available at: https://apps.who.int/iris/ bitstream/handle/10665/44583/9789241501491_ eng.pdf?ua=1. Accessed October 10, 2019

22. Ashwell M, Cole TJ, Dixon AK. New insight into the anthropometric classification of fat distribution shown by computed tomography. Br Med J Clin Res Ed 1985;290:1692-1694. https://doi.org/10.1136/ bmj.290.6483.1692

23. Wajchenberg BL, Gianella-Neto D, da Silva ME, Santos RF. Depot-spesific hormonal characteristics of subcutaneous and visceral adipose tissue and their relation to the metabolic syndrome. Horm Metab Res 2002;34:616-621. https://doi. org/10.1055/s-2002-38256

24. Wajchenberg BL. Subcutaneous and visceral adipose tissue: their relation to the metabolic syndrome. Endocr Rev 2000;21:697-738. https://doi.org/10.1210/ edrv.21.6.0415

25. BrittonKA, Fox CS. Ectopicfat depots and cardiovascular disease. Circulation 2011;124:837-841. https://doi. org/10.1161/CIRCULATIONAHA.111.077602

26. Ryo M, Maeda K, Onda T, et al. A new simple method for the measurement of visceral fat accumulation by bioelectrical impedance. Diabetes Care 2005;28:451453. https://doi.org/10.2337/diacare.28.2.451

27. Odegaard JI, Chawla A. Pleiotropic actions of Insulin resistance and Inflammation in metabolic homeostasis. Science 2013;339:172-177. https://doi.org/10.1126/ science. 1230721

28. Bozkuş Y, Mousa U, Demir CC, et al. Abdomınal bıoelectrıc ımpedance for follow-up of dieters: a prospective study. Acta Endocrinol (Buchar) 2019;15:145-152. https://doi.org/10.4183/ aeb.2019.145

29. Mousa U, Kut A, Bozkuş $Y$, Demir Çicek C, Anil C, Tütüncü Bascil N. Performance of abdominal bioelectrical impedance analysis and comparison with other known parameters in predicting the metabolic syndrome. Exp Clin Endocrinol Diabetes 2013;121:391396. https://doi.org/10.1055/s-0033-1341473
30. Onat A, Hergenç G, Can G. İki metabolik sendrom tanımının kardiyometabolik risk öngörüsünün aynı kohortta prospektif yolla değerlendirilmesi ve halkımız için en uygun tanımın seçilmesi. Anadolu Kardiyol Derg 2007;7:29-34.

31. Lee S, Choi S, Kim HJ, et al. Cutoff values of surrogate measures of insulin resistance for metabolic syndrome in Korean non-diabetic adults. J Korean Med Sci 2006;21:695-700. https://doi.org/10.3346/ jkms.2006.21.4.695

32. Esteghamati $\mathrm{A}$, Ashraf $\mathrm{H}$, Khalilzadeh $\mathrm{O}$, et al. Optimal cut-off of homeostasis model assessment of insulin resistance (HOMA-IR) for the diagnosis of metabolic syndrome: third national surveillance of risk factors of noncommunicable diseases in Iran (SuRFNCD-2007). Nutr Metab 2010;7:26. https://doi.org/10.1186/17437075-7-26

33. Esteghamati $A$, Ashraf $H$, Esteghamati $A R$, et al. Optimal threshold of homeostasis model assessment for insulin resistance in an Iranian population: the implication of metabolic syndrome to detect insulin resistance. Diabetes Res Clin Pract 2009;84:279-287. https://doi.org/10.1016/j.diabres.2009.03.005

34. Onat A, Hergenç G, Türkmen S, Yazıcı M, Sarı I, Can G. Discordance between insulin resistance and metabolic syndrome: features and associated cardiovascular risk in adults with normal glucose regulation. Metabolism 2006;55:445-452. https://doi. org/10.1016/j.metabol.2005.10.005

35. UKPDS Group. U.K. Prospective Diabetes Study 16. Overview of 6 years' therapy of type II diabetes: a progressive disease. Diabetes 1995;44:1249-1258.

Teşekkür: 53. Ulusal Diyabet Kongresinde (Girne, KKTC, 22.4.2017) sözlü olarak sunulmuştur.

Araştırma kurulu onayı: $\mathrm{Bu}$ çalışma Başkent Üniversitesi Tıp ve Sağlık Bilimleri Araştırma Kurulu tarafından KA19/405 proje kodu ile 17/12/2019 tarihinde onaylanmıştır. 